\title{
EDUKASI CARA MENCUCI TANGAN MEMAKAI SABUN YANG BAIK DAN BENAR DI PANTI ASUHAN TERIMAKASIH ABADI MEDAN
}

\author{
Novita Aryani ${ }^{1}$, Marthalena Simamora ${ }^{2}$ Friska M.Parapat ${ }^{3}$ \\ 1,2 Prodi S1 Keperawatan USM Indonesia ${ }^{3}$ Prodi S1 Kebidanan USM Indonesia \\ novitaaryaniusm@gmail.com .marthasimamorausm@gmail.com chamidwifeparapat@gmail.com
}

\begin{abstract}
ABSTRAK
Wabah Covid-19 yang disebabkan virus corona menyebar keseluruh negara di dunia. Infeksi virus ini menimbulkan gangguan dengan gejala ringan pada sistem pernafasan sampai terjadi infeksi paru-paru berat bahkan bisa terjadi kematian. Percikan dahak yang mengandung virus corona masuk kedalam tubuh melalui mata, hidung, tenggorokan dan biasanya terjadi melalui tangan yang terkontaminasi virus corona. Cara memutus penularan penyebaran virus yang paling sederhana dan penting tanpa biaya yang mahal adalah dengan cara mencuci tangan memakai sabun dan air. Tujuan pengabdian masyarakat ini adalah untuk meningkatkan pengetahuan anak panti asuhan tentang cara mencuci tangan yang baik dan benar dengan menggunakan sabun dan air. Metode yang digunakan adalah ceramah dilanjutkan dengan demonstrasi serta praktik mencuci tangan. Hasil edukasi tentang cara mencuci tangan memakai sabun dan air dapat dilihat dari selisih nilai rata-rata pengetahuan anak panti sebelum dan sesudah dilakukan edukasi yaitu sebesar 1.40. Pemberian penyuluhan tentang cara mencuci tangan pada anak panti dapat meningkatkan pengetahuan dan ketrampilan mereka dalam menghadapi penyebaran virus corona.
\end{abstract}

Kata Kunci: Covid 19, Mencuci Tangan Memakai Sabun

\begin{abstract}
The Covid-19 outbreak caused by the corona virus has spread to all countries in the world. This viral infection causes disturbances with mild symptoms in the respiratory system to severe lung infections and even death. Sprinkling of phlegm containing the corona virus enters the body through the eyes, nose, throat and usually occurs through hands contaminated with the corona virus. The simplest and most important way to stop the spread of the virus without being expensive is to wash your hands with soap and water. The purpose of this community service is to increase the knowledge of orphanage children about how to wash hands properly and correctly using soap and water. The method used is a lecture followed by a demonstration and the practice of washing hands. The results of education on how to wash hands using soap and water can be seen from the difference in the average value of knowledge of orphans before and after education, which is 1.40. Providing counseling on how to wash hands for orphanage children can improve their knowledge and skills in dealing with the spread of the corona virus.
\end{abstract}

Keywords: Covid 19, Washing Hands With Soap

\section{PENDAHULUAN}

Penyebaran virus corona berlangsung cukup cepat ditandai dengan penambahan jumlah kasus Covid-19 diseluruh dunia. Dimulai dari ditemukannya kasus pneumonia di Kota Wuhan Propinsi Hubei Negara China pada tahun 2019 yang tidak diketahui penyebab penyakit tersebut. Setelah diidentifikasi ternyata kasus pneumonia ini 
disebabkan adanya varian baru virus corona. Lalu pada tanggal 30 Januari 2020 WHO menetapkan kasus Covid-19 ini sebagai Kedaruratan Kesehatan Masyarakat yang Meresahkan Dunia (KKMMD) dan akhirnya pada tanggal 11 Maret 2020 ditetapkan sebagai pandemi (Kemendagri RI., 2020).

Negara Indonesia dikategorikan sebagai negara yang termasuk baru terinfeksi virus corona. Tetapi dalam waktu yang singkat jumlah orang yang positif terinfeksi covid -19 meningkat dengan cepat. Saat ini jumlah mereka yang terinfeksi pertanggal 18 Maret 2021 bertambah sebanyak 6.570 kasus sehingga total menjadi sekitar 1.443 .853 kasus, dengan jumlah pasien sembuh meningkat sejumlah 6.285 orang sehingga total sekitar 1.272 .958 orang. Pasien meninggal juga meningkat 227 orang sehingga menjadi total sekitar 39.142 orang (Wisnoe, 2021)

Klaster penularan virus corona di Indonesia semakin bertambah. Klaster pertama adalah klaster Jakarta, yang bersumber dari WNA asal Negara Jepang yang positif Covid-19 dan berkunjung ke Jakarta. Klaster adalah satu kelompok dengan satu kejadian kesehatan yang sama, yang terjadi dalam area dan waktu yang sama. Hingga saat ini klaster yang paling banyak menyumbangkan kasus covid-19 terbanyak adalah kluster Secapa Angkatan Darat Kota Bandung. Dimana tercatat sebanyak 1.262 orang siswa dan pelatih Scapa Angkatan Darat tertular covid 19. Pakar epidemiologi dari Universitas Griffith, Australia, Dicky Budiman, menyebut klaster keluarga (tinggal serumah) bisa berkontribusi hingga 85\% terhadap penambahan pasien positif covid 19 jika tidak ada langkah cepat untuk mengatasinya (Azanelia, 2021).

Melaksanakan kebersihan tangan secara rutin dapat menghindari penyebaran virus corona karena virus bisa masuk kedalam tubuh melalui mata, hidung dan tenggorokan melalui tangan yang sudah terinfeksi virus corona. Jika tangan yang terkena virus menyentuh hidung, mata dan mulut, maka virus Covid-19 akan masuk ke paru-paru kemudian merusak sistem paru-paru yang dapat mengakibatkan sesak napas, dan jika sistem imun sedang rendah dapat menyebabkan gagal pernapasan (Naufal. 2020)

Kecepatan penyebaran virus corona dapat diatasi dengan memutuskan mata rantai penularan dengan melaksanakan perubahan perilaku kesehatan masyarakat. Masyarakat dihimbau untuk selalu mengikuti protokol kesehatan yaitu mencuci tangan dengan benar, menggunakan masker, membatasi aktivitas di luar rumah, menghindari kerumunan, melakukan social distancing diikuti dengan proses belajar, bekerja, dan beribadah di rumah serta melakukan disinfeksi benda/permukaan yang diduga terinfeksi oleh virus corona (Yunus, dkk. 2020).Salah satu tindakan pencegahan yang harus dilakukan tanpa biaya mahal dan penting dilakukan adalah dengan mencuci tangan memakai sabun (CTPS). CTPS yang dilakukan secara benar terbukti efektif dalam menjaga kesehatan dibandingkan dengan mencuci tangan dengan air saja. (BNPB, 2020).

Menurut penelitian Hasanah \&Mahardika (2021) perilaku mencuci tangan memakai sabun merupakan suatu upaya yang memiliki dampak besar bagi pencegahan penyakit-penyakit menular seperti diare dan ISPA. namun mencuci tangan masih belum membudaya dimasyarakat karena berbagai faktor seperti pengetahuan yang kurang, dan kesadaran yang rendah dalam melakukan cuci tangan memakai sabun. Hasil penelitian tersebut sejalan dengan penelitian Oktaviani \& Hairunisa (2020) yang menyebutkan bahwa kurangnya kesadaran mencuci tangan dengan sabun masih banyak terjadi di kalangan masyarakat, termasuk anak-anak. Hal tersebut dapat dilihat ketika mereka selesai bermain, masih ada saja anak yang tidak mencuci tangannya, kemudian saat mau makan, masih ada anak yang lupa mencuci tangannya terlebih dahulu. 
Sekumpulan anak terlantar, yatim piatu dan anak dari keluarga ekonomi lemah biasanya ditampung di panti asuhan sebagai tempat tinggal mereka. Kehidupan didalam panti yang sederhan seperti makan satu tempat dan tidur bersama-sama dalam satu ruangan sudah menjadi budaya tersendiri. Hal ini dilakukan pihak panti untuk membangun nilai kebersamaan di antara anak satu dengan anak lainnya dan ada juga dikarenakan faktor kekurangan ekonomi pengelola panti asuhan.

Berdasarkan pengamatan yang dilakukan tim pengabdian didapati bahwa prilaku anak yatim piatu dalam melakukan cuci tangan memakai sabun setelah anak beraktifitas diluar panti, setelah bermain bersama dihalaman panti masih kurang. Data tersebut menjadi acuan tim pengabdian untuk melakukan kegiatan. Adapun tujuan pengabdian masyarakat ini adalah untuk menambah wawasan pengetahuan anak panti asuhan tentang mencuci tangan yang baik dan benar dengan menggunakan sabun guna mencegah penuluran virus corona di Panti Asuhan Terimakasih Abadi Medan.

\section{METODE}

Kegiatan pengabdian dilakukan dalam bentuk penyuluhan tentang bagaimana cara mencuci tangan dengan memakai sabun dan air yang benar. Metode penyuluhan yang dipakai adalah secara teori dan praktek mencuci tangan, dan dilakukan juga pre dan post test sebagai evaluasi kegiatan penyuluhan. Evaluasi objektif dilakukan penyuluh secara langsung bertanya saat dilakukan penyuluhan dan saat diskusi terkait materi yang disampaikan pada saat penyuluhan. Untuk evaluasi subjektif dilakukan ekspress feeling setelah berakhirnya

kegiatan pengabdian.

\section{HASIL DAN PEMBAHASAN}

Pelaksanaan pengabdian dihadiri oleh pihak yayasan panti, kepala asrama panti dan tim dari pengabdian masyarakat. Setelah kata sambutan dari ketua pengabdian dan yayasan panti, acara kemudian dilanjutkan dengan penyuluhan tentang cara melakukan cuci tangan memakai sabun dan dilanjutkan dengan mempraktekkan langsung cara mencuci tangan dengan tehnik 7 langkah memakai sabun dan air mengalir ditempat yang sudah disediakan. Sebelum dilakukan penyuluhan, terlebih dahulu dilakuan pengukuran awal (pre test) untuk mengetahui tingkat pengetahuan anak panti asuhan tentang cara melakukan cuci tangan dengan tehnik 7 langkah menggunakan sabun dan air. Pengukuran awal tersebut dilakukan dengan memberikan anak-anak 5 buah pertanyaan tentang cara mencuci tangan denga tehnik 7 langkah. Dan berdasarkan hasil pretest didapat data bahwa rata-rata tingkat pengetahuan siswa adalah 3,20. 


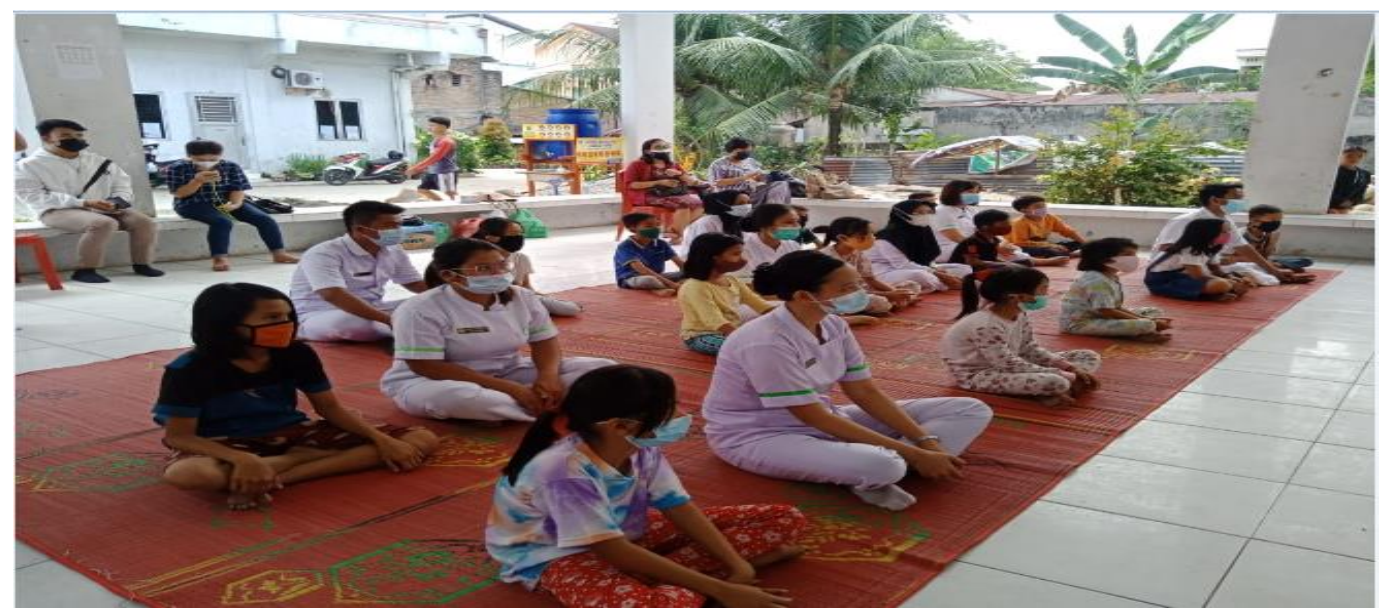

Gambar1. Kegiatan Pemberian Penyuluhan Tentang Cara Mencuci Tangan dengan tehnik 7 Langkah

Pelaksanaan penyuluhan berlangsung selama 1,5 jam, yang terdiri dari 3 sesi, sesi pertama berupa pemaparan materi dari penyuluh, sesi kedua tanya jawab tentang materi yang disampaikan, dan sesi ketiga melakukan praktek langsung tentang caura mencuci tangan dengan tehnik 7 langkah menggnakan sabun dan air mengalir. Materi yang disampaikan selama penyuluhan membahas tentang pengertian mencuci tangan pmemakai sabun (CTPS), kapan saja harus melakukan cuci tangan, dampak penyakit yang ditimbulkan jika tidak selalu mencuci tangan, serta cara mencuci tangan dengan tehnik 7 langkah yang benar.n. Pada sesi kedua antusias anak untuk bertanya sangat tinggi, terbukti dari banyaknya anak yang bertanya. Pada sesi ketiga anak melakukan praktek dibantu oleh tim pengabdian dengan bergiliran maju ke kran air yang mengalir.

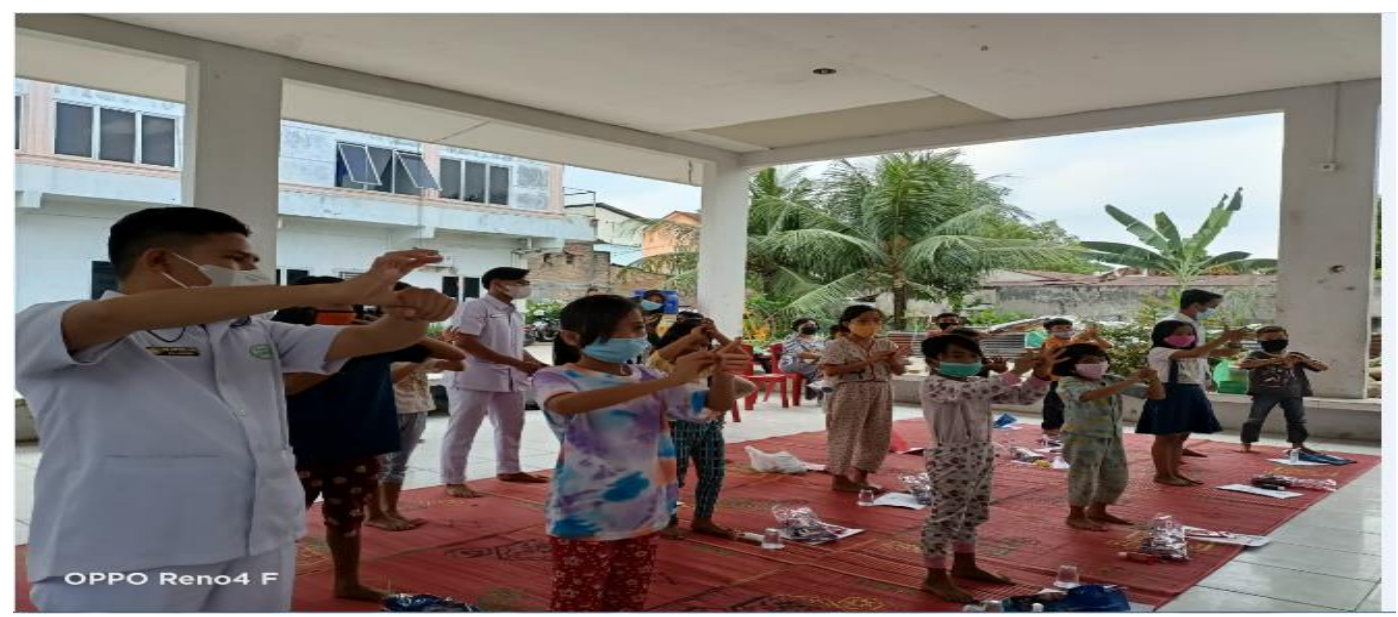

Gambar 2. Kegiatan Edukasi Tentang Cara Mencuci Tangan dengan Tehnik 7 Langkah yang benar 


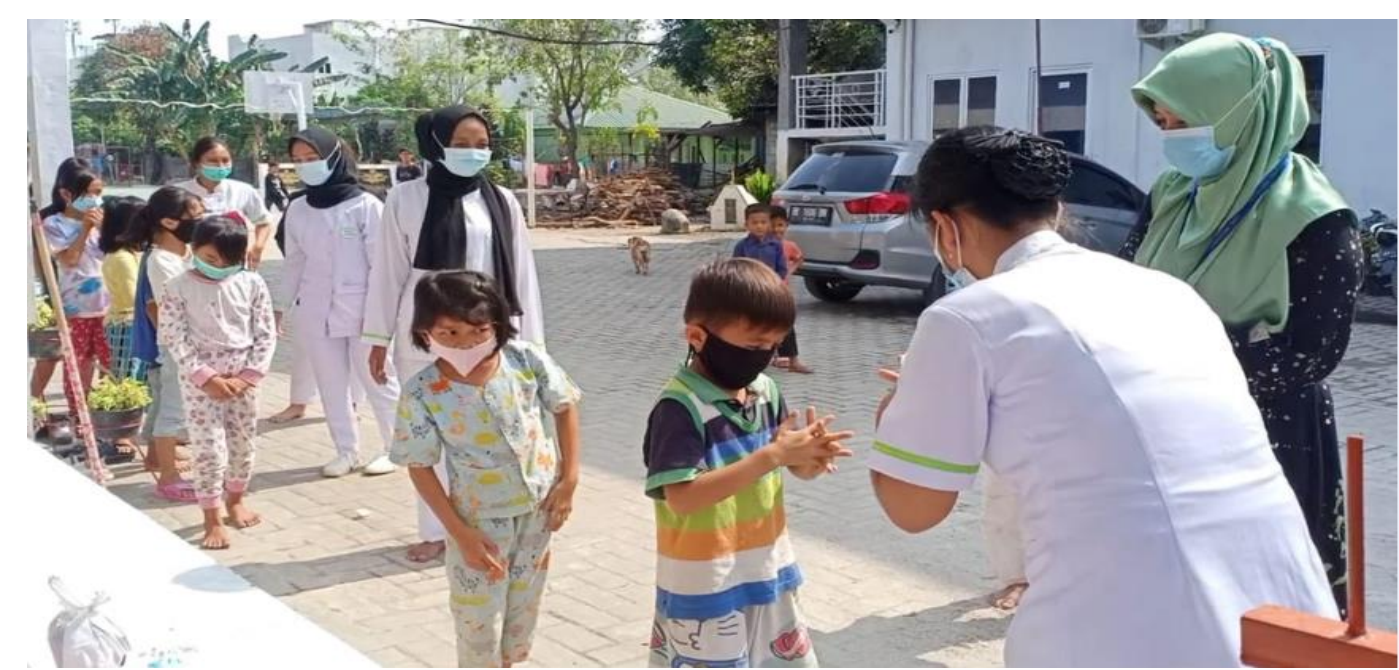

Gambar 3. Kegiatan Praktek Cara Mencuci Tangan dengan Tehnik 7 Langkah

Sebelum penyuluhan ditutup dilakukan lagi pengukuran pengetahuan (post test) untuk mengukur tingkat pengetahuan anak panti setelah materi disampaikan. Setelah dilakukan pengolahan data, didapat bahwa tingkat pengetahuan anak panti terkait cara mencuci tangan dengan tehnik 7 langkah yang benar meningkat secara signifikan yaitu menjadi 4,6. Artinya terjadi peningkatan pengetahuan siswa dari 3.20 menjadi 4.60.

Tabel 1. Rata-Rata Pengetahuan Anak Panti Tentang Mencuci Tangan dengan Tehnik 7 Langkah

\begin{tabular}{ccc}
\hline Kategori & Rata-Rata & Selisih \\
\hline Pre Test & 3.20 & 1.40 \\
Post Test & 4.60 & \\
\hline
\end{tabular}

Rata-Rata selisih Pre Test 3.20 dan Post Test 4.60 adalah 1.40 Pada akhir penyuluhan, anak panti diberikan hand sanitiser, masker penutp hidung, buku menggambar dan pensil mewarnai sebagai kenang-kenangan untuk dibawa pulang dan kemudian anak panti diberikan kesempatan mengungkapkan perasaannya tentang penyuluhan yang dilakukan saat itu. Dan dari ekspresi feeling tersebut banyak anak panti yang mengatakan sangat tertarik dalam mempelajari tehnik 7 langkah dalam mencuci tangan menggunakan sabun dan air. Karena topik ini merupakan sesuatu yang penting bagi mereka dan mengharapkan agar kegiatan seperti ini dilakukan secara berkesinambungan.

\section{PEMBAHASAN}

Hasil pengukuran tingkat pengetahuan anak panti asuhan tentang cara mencuci tangan dengan tehnik 7 langkah yang dilakukan tim pengabdian menunjukkan terjadi peningkatan pengetahuan yaitu sebesar 1.40. dibandingkan sebelum dilakukan penyuluhan. Manfaat edukasi yang dilakukan pada pengabdian masyarakat ini diharapkan anak-anak yatim dapat meningkatkan ilmu pengetahuannya dan dapat 
melakukan tindakan mencuci tangan pada saat mereka setelah bermain dan setelah memegang benda.

Ilmu pengetahuan seorang individu terjadi melalui penginderaan dari panca indera manusia. Sebagian besar pengetahuan tersebut diperoleh melalui penglihatan dan pendengaran. Pengetahuan atau kognitif merupakan domain yang sangat penting untuk terbentuknya perilaku seseorang. Prilaku yang berdasarkan pengetahuan yang baik akan lebih langgeng apabila daripada perilaku yang tidak didasari oleh pengetahuan. Karena itu pada awal kegiatan edukasi ini penyuluh memberi penjelasan terlebih dahulu tentang manfaat perilaku dan resiko apabila tidak melakukan mencuci tangan dengan 7 langkah dengan sabun dan air.

Tindakan tehnik 7 langkah mencuci tangan dengan memakai sabun dan air adalah salah satu tindakan memutuskan mata rantai penyebaran virus corona. Penggunaan sabun dan air saat mencuci tangan menjadi efektif karena kandungan antiseptik yang ada didalam sabun serta lemak dan kotoran yang menempel pada tangan akan terlepas saat tangan saling bergesekan saat mencuci tangan. Di dalam lemak dan kotoran yang menempel inilah kuman penyakit dapat hidup. Tangan sering kali menjadi agen yang membawa kuman dan menyebabkan patogen berpindah dari satu orang ke orang lain, baik dengan kontak langsung ataupun kontak tidak langsung menggunakan permukaanpermukaan lain seperti handuk, gelas (Hasanah, 2021).

Kandungan antiseptik didalam sabun adalah alkohol. Alkohol memiliki spektrum yang baik untuk kuman gram positif, gram negatif, basil tuberkulosis, jamur, dan virus termasuk RSV (respiratory syncytial virus), virus hepatitis A, B, dan HIV. Alkohol bekerja dengan cara merusak dinding sel bakteri. Alkohol dalam konsentrasi yang tepat menghasilkan efek yang cepat dan secara nyata menurunkan jumlah mikroba merugikan di kulit. (Oktaviani \& Hairunnisa, 2020).

Keberhasilan pelaksanaan menerapkan mencuci tangan dengan sabun dan air ini banyak sekali faktor yang menjadi perhatian dalam mewujudkan keberhasilan pelaksanaannya. Diantara nya adalah citra diri, status sosial ekonomi, kebiasaan anak, sikap, pola asuh, ketersediaan sabun dan air bersih /wastafel. Kesemua faktor -faktor ini merupakan satu kesatuan yang saling mendukung agar prilaku mencuci tangan memakai sabun dapat terwujud (Kushartanti, 2012)

\section{PENUTUP}

\section{Kesimpulan}

Pemberian edukasi yang dilakukan pada anak Panti Asuhan Terimakasih Abadi berdampak positif (signifikan) terhadap tingkat pengetahuan anak dalam cara mencuci tangan yang benar guna mencegah terinfeksi virus covid- 19 .

Saran

Untuk anak panti asuhan selalulah mempraktekkan kegiatan cuci tangan dengan tehnik 7 langkah guna menghindari terinfeksi virus corona Untuk pihak panti asuhan sedikanlah tempat anak-anak melakukan cuci tangan baik didalam ruangan kelas, ruangan kamar tidur dan tempat anak-anak berkumpul bermain. Untuk Pendidikan Keperawatan 
teruslah melakukan penyuluhan-penyuluhan berkesinambungan terhadap masalahmasalah kesehatan yang terjadi saat ini maupun yang beresiko akan terjadi

\section{REFERENSI}

Azanelia A.L, (2021).Klaster keluarga Covid-19: Terjadi di lima kota besar di Indonesia, pakar sebut bisa berkontribusi hingga 85\% terhadap peningkatan kasus positif . Diakses di https://www.bbc.com/indonesia/indonesia-54106027

BNPB (Badan Nasional Penanggulangan Bencana). 2020. Bersatu Lawan COVID-19. Gugus Tugas Percepatan Penanganan Covid-19.

Direktorat Jenderal Pencegahan dan Pengendalian Penyakit. 2020. Pedoman Kesiapsiagaan Menghadapi Coronavirus Disease (COVID-19) Maret 2020.Kementerian Kesehatan Republik Indonesia. Jakarta.

Hasanah, U., \& Mahardika, D. R. (2021). Edukasi Prilaku Cuci Tangan Pakai Sabun Pada Anak Usia Dini Untuk Pencegahan Transmisi Penyakit. In Prosiding Seminar Nasional Pengabdian Masyarakat LPPM UMJ (Vol.1, No. 1). https://jurnal.umj.ac.id/index.php/semnaskat/article/view/7972

Kushartanti, R.(2012). Beberapa faktor yang mempengaruhi perilaku cuci tangan pakai sabun (studi di Sekolah Dasar Negeri Brebes 3) (Doctoral dissertation, Program Pascasarjana Undip).

Oktaviani, S., \& Hairunnisa, H. (2020). Penyuluhan Cuci Tangan Pada Anak-Anak Warga RT.14 Kelurahan Jawa Samarinda Ulu. Jurnal Pengabdian UntukMu NegeRI, 4(2), 247-251.https://doi.org/10.37859/jpumri.v4i2.2123

Naufal D. A. 2020. Penjelasan Para Ilmuan SoalSifat Covid-19 dan Penyebaran yang Ekstrem. Artikel Tribunstyle.com

Wisnoe M (2021). Data Terkini Korban Virus Corona di Indonesia pada Maret 2021. Diakses di https://www.merdeka.com/peristiwa/data-terkini-korban-virus-coronadi-indonesia-padamaret-2021.html)

Yunus, dkk. 2020. Kebijakaan pemberlakuan lockdown sbagai antisipassi penyebran corona virus covid 19. Salam; Jurnal Sosial dan budaya syarii FSH UIN Syarif Hidayahtullah Jakarta. Vol. 7 no. 3 (2020), pp.227-238, DOI: $10.15408 /$ sjsbs.v7i3.15083 